\title{
Trans-Atlantic Connection: The Link Between American and Nazi Eugenics
}

\author{
Shaun Williamson
}

Nazi eugenics programs of the 1930s and 1940s led to one of the most horrific events in human history, the Holocaust. They were not, however, formed in an international vacuum. There were many connections between the American eugenics movement of the late 19th and early 20th centuries and the Nazi Government of Germany's eugenics policies that culminated in the Holocaust. The link between the Nazi eugenics movement and it's American counterpart are revealed through direct communication and expressions of mutual admiration; financial ties between America and Nazi eugenics research institutions; and a variety of more ephemeral personal and intellectual connections that linked the German and American movements.

British academic Francis Galton first coined the term "eugenics" in his 1883 book Inquiries Into Human Faculty and Its Development ${ }^{1}$, however he had been been writing about the idea as early as 1869 with the publication of his book Hereditary Genius. Galton based the term eugenics on the Greek word "eugenes", and stated that its definition was the "science of improving stock, which is by no means confined to questions of judicious mating," but also "cognisance of all influences that tend to in however remote a degree give to the more suitable races or strains of blood a better chance of prevailing." ${ }^{2}$ Galton's work on eugenics was inspired by his cousin, famous naturalist, and father of the theory of evolution, Charles Darwin and Darwin's 1859 book On the Origins of Species. Galton was particularly influenced by the first chapter of the book entitled "Variation under Domestication", which focused on the breeding of domestic animals. ${ }^{3}$ Early in the $20^{\text {th }}$ century, Galton observed in reference to selective breeding practices utilized by farmers on livestock: "could not the race of men be similarly improved? Could not the undesirables be got rid of and the desirables multiplied?" 4 It is clear from this statement that Galton's interest in the subject of selective breeding, which in Darwin's work was confined to selective breeding of domestic animals, not only favoured the selective breeding of humans, but also endorsed the concept of negative eugenics, which is the practice of "discouraging

\footnotetext{
${ }^{1}$ Francis Galton, Inquiries Into Human Faculty and Its Development (London: Macmillan, 1883), 24.

${ }^{2}$ Ibid, 17.

${ }^{3}$ Derek William Forrest, Francis Galton: The Life and Work of a Victorian Genius (London: Taplinger Pub Co, 1974), 103.

${ }^{4}$ Karl Pearson, The Life, Letters and Labours of Francis Galton, Volume 3 (Cambridge: Cambridge University Press, 1930) 348.
} 
breeding of those presumed to have undesirable genes." ${ }^{5}$ This new mindset would become the basis for most popular eugenics movements of the early 20th century.

In the years following Galton's Inquiries Into Human Faculty and Its Development, scientists and activists continued to focus on the new field of eugenics, and the movement grew increasingly popular and accepted. The development and popularization of negative eugenics during this period eventually led to the American state of Indiana passing the first compulsory sterilization law in the world in 1907. The law "entitled an act to prevent procreation of confirmed criminals, idiots, imbeciles and rapists" if "a committee of experts, consisting of two physicians" deemed the action necessary. ${ }^{6}$ By 1914, twelve other states followed suit with similar compulsory sterilization laws.

The eugenics movement gained widespread international support in the early 20th century. Both American and European eugenicists gathered together at the First International Eugenics Congress of 1912. The Congress was sponsored by Charles Darwin's son and head of the British Eugenics Education Society, Leonard Darwin. Attendees at the conference included the famous inventor Alexander Graham Bell, the director of the American Eugenics Record Office Charles B. Davenport, as well as the presidents of Harvard and Stanford Universities. England was represented by Winston Churchill, who was at the time Secretary of State for Home Affairs, as well as the Vice-Chancellor of the University of London. The inventor of the phrase "racial hygiene", Alfred Ploetz, and Max von Gruber, who was a professor of hygiene in Munich, represented Germany. Representatives from France, Switzerland, Norway, and Greece were also in attendance. The invitation to the Congress explained that it would "make more widely known the results of the investigations of those factors which are making for racial improvement or decay" and "discuss to what extent existing knowledge warrants legislative action." It was hoped that an "International Committee" would be founded to facilitate the "cooperation of existing societies and workers." ${ }^{7}$

The United States was clearly an inspiration to European eugenicists. During the First World War, German eugenicist, Alfred Ploetz, leader of an organization called the German Society for Racial Hygiene, praised the American eugenics movement through the distribution of flyers citing "the dedication with which Americans sponsor research in the field of racial hygiene and with which they translate theoretical knowledge into practice." The flyer also extolled the restrictive immigration policies of the United States, and commended the fourteen states which had instituted the aforementioned mandatory sterilization laws. The flyer also posed the question: "Can we have any doubts that the Americans will reach their aim - the stabilization and improvement of the strength of the people?"8 It is clear from this flyer that early German proponents of eugenics were closely

\footnotetext{
${ }^{5}$ Robert C. King, Pamela K. Mulligan, William D. Stansfield. "Eugenics" in A dictionary of Genetics (Oxford: Oxford University Press, 2013),http://library.mtroyal.ca:2299/view/10.1093/acref/9780199766444. 001.0001/acref-9780199766444-e-2199.

6 “1907 Indiana Eugenics Law," last modified May 7, 2013, http://en.wikisource.org/wiki/ 1907_Indiana_Eugenics_Law.

${ }^{7}$ Stefan Kuhl, The Nazi Connection: Eugenics, American Racism, and German National Socialism (Oxford: Oxford University Press, 2001), 14.

${ }^{8}$ Ibid, 15.
} 
watching the eugenics movement in the United States, and were to some extent inspired and encouraged by the American movement.

German eugenicists were able to follow developments in American eugenics thanks in large part to Geza von Hoffmann. Hoffmann was an Austrian-Hungarian writer, who also worked for a period of time as the Austrian Vice-Consulate in California. In 1909, California became the third state in America to enact a mandatory sterilization law. California also had by far the most forced sterilizations in the country, and by 1921 accounted for $80 \%$ of all mandatory sterilization in America. ${ }^{9}$ While in California, Hoffmann closely observed the implementation of eugenics laws and in 1913 published his observations in a book entitled Die Rassenhygiene in den Vereinigten Staaten von Nordamerika. The book described in favourable terms how the theories that were common amongst many European eugenicists were being implemented in America. Hoffmann was not only in favour of the forced sterilization programs in the United States, but also the prevalent anti-miscegenation laws which banned interracial marriage. ${ }^{10}$ Race mixing was something that most eugenicists agreed should be avoided, as they believed that race mixing would diminish the genes of the of those who they deemed genetically superior.

Hoffmann's book received positive reviews in America. In one review, published in 1914 in the Journal of the American Institute of Criminal Law and Criminology, the American reviewer commended Hoffmann for writing the book, and applauded its potential to "imbue his readers with some of our utilitarianism." The reviewer was pleased with Hoffman's statement that, in regards to eugenics, "America is in no way radical, it is only rational to the point of sobriety." He concluded his review by stating that "those with access to the German language should feel grateful to the author for his excellent presentation of the present status of this subject."11 Hoffman was impressed with American eugenicist policies and this reviewer, clearly, basked in his praise.

In 1914, Hoffmann published an article entitled "Eugenika." In the article, Hoffmann shifted his focus from reporting on the American eugenics movement to trying to formulate a plan for eugenics in his home country of Hungary. Hoffmann called for Hungary's public institutions to "promote a strong eugenics policy." Hoffmann's works were influential in uniting the somewhat splintered eugenics movement of Central Europe. ${ }^{12}$

During the First World War, the connections between American and German Eugenicists were drastically reduced. Germany did not send any delegates to the Second International Eugenics Congress of 1921, which occurred in New York City. At the Second International Eugenics Congress, Alexander Graham Bell served as the honorary president, and the keynote speaker was Leonard Darwin. Darwin called for the use of x-ray to "prevent descendants from the feeble-minded and habitual criminals." He also urged for the segregation of the "wastrel, the habitual drunkard and the work-shy" in order to stop those traits from existing in future generations. He also said that "sound and fit and

\footnotetext{
9 “Eugenics in California," last modified 2012, http://eugenicsinamerica.weebly.com/eugenics-incalifornia.html.

${ }^{10}$ Marius Turda and Paul Weindling, Blood and Homeland: Eugenics and Racial Nationalism in Central and Southeast Europe, 1900-1940, (Herndon: Central European University Press, 2006) 200.

${ }^{11}$ Bernard Glueok, "Reviews and Criticisms," Journal of the American Institute of Criminal Law and Criminology, Vol. 4, No. 6 (Mar., 1914), 934-935.

12 Turda and Weindling, Blood and Homeland, 201.
} 
superior people should, by a campaign of patriotism, be induced to raise larger families," which was a policy that the Nazis would later promote. ${ }^{13}$

German Eugenicists re-entered the international eugenics conversation in 1925. Prominent German eugenicist, and leader of the Munich chapter of the German Society for Race Hygiene, Fritz Lenz, succeeded Hoffmann as the main link between American and German Eugenicists. Lenz wrote of the similarities between the positions of Eugenicists in the United States and Germany in a 1924 article entitled "Eugenics in Germany," claiming that there were almost no differences. Lenz believed one of the only differences was in legislation, in respect to which, Lenz claimed that Germany was trailing America. He stated that "the Germans are more disposed toward scientific investigation than toward practical statesmanship," but thought in time German legislation would catch up to the United States. ${ }^{14}$ As will become apparent, Lenz's optimism regarding the future of eugenics in Germany was not unfounded. German historian Reinhold Muller, writing in 1934, reflected upon Lenz's views saying: "Racial hygiene in Germany remained until 1926 a purely academic and scientific movement. It was the Americans who busied themselves earnestly about the subject."15 At this point in the eugenics movement it was fairly clear that German eugenicists were looking up to the legislation that American eugenicists had been able to pass, and hoped to do the same within their own country.

Although the relations between German and American eugenicists were strained during the First World War, the war did not stop the progress of the international eugenics movement as a whole. In 1916, American eugenicist and amateur anthropologist Madison Grant published The Passing of the Great Race; or, The racial basis of European History which is notable for establishing Nordic theory. The Passing of the Great Race is split into two parts. In the first part, Grant wrote about the then current eugenics movement, focusing mostly on America, and the basic principles of scientific racism. In the second part of his book, Grant presented a history of Europe based almost exclusively on race. The fall of Alexander the Great's empire, for example, was due to Macedonian blood mixing with Asiatic blood. Social divisions between patricians and plebeians, in Grant's view, were explicable as racial divisions between Nordics and Mediterraneans. And, the decline of the Spanish empire was due to the dilution of Gothic blood. ${ }^{16}$ Every historical event, in short, could be racially explained.

Nordic theory is based upon Grant's belief that Europeans were separated into three distinct races of varying intrinsic quality; the Alpine, Mediterranean, and Nordic, which was also known as Aryan. Grant believed the Nordics were the superior race. A Nordic was "the white man par excellence" and the race was "characterized by certain unique specializations, namely, wavy brown or blond hair and blue, gray or light brown eyes, fair skin, high, narrow and straight nose, which are associated with great stature, and a long skull, as well as with abundant head and body hair."17 Although Grant believed the Nordic race to be the apex of the human race, he also believed that the Nordic race "was heading

\footnotetext{
13 “Want More Babies in Best Families," New York Times, September 25, 1921.

${ }^{14}$ Fritz Lenz, "Eugenics in Germany," trans. Paul Popenoe, Journal of Hereditary, 15 (5): 223-231), 223.

15 Robert Proctor, Racial Hygiene: Medicine Under the Nazis (Cambridge: Harvard University Press, 1990 ), 98.

16 Jonathan Spiro, Defending the Master Race: Conservation, Eugenics, and the Legacy of Madison Grant (Burlington: Vermont, 2008), 145.

17 Madison Grant, The Passing of the Great Race (4 ed.) (New York: C. Scribner's sons, 1921) 167.
} 
toward destruction as a result of war, climate, alcoholism, disease, voluntary race suicide and, in the United States, intermixture with inferior immigrant stock."18 Grant called for the state to "destroy sickly infants and sterilized defective adults who were of no value to the community."19 Many of these beliefs were also shared by the Nazi Party, which formed three years after the book's publication.

The Passing of the Great Race was quite popular in the United States, and contributed to the passing of the Immigration Act of 1924. It had many famous fans, including former American President Theodore Roosevelt, who in a letter to Grant wrote: "this book, is a capital book; in purpose, in vision, in grasp of the facts our people most need to realize" and that "all Americans should be sincerely grateful to you for writing it." ${ }^{20}$ The book was translated into German in 1925. At least five publishers fought for the rights to publish the German edition of the book. The rights were eventually won by German book publisher J.F. Lehmann. Lehmann was an associate of the eventual Nazi Fuhrer of Germany, Adolf Hitler, and a member of the Nazi Party since 1920. The book proceeded to become popular in Central Europe. In the early 1930s, Hitler sent a letter to Grant in which he stated, in reference to The Passing of the Great Race, that "this book is my bible."21

The Passing of the Great Race was not Madison Grant's only contribution to eugenics. From 1922 until his death in 1937, Grant served as president of the Immigration Restriction League. The Immigration Restriction League had been in operation since 1894 and aimed to prohibit immigrants coming from southern and eastern Europe and bringing with them poverty and organized crime. ${ }^{22}$ The League did not make a major impact until 1918, when it successfully introduced a bill into Congress that would restrict immigration of southern and eastern Europeans, while allowing for more northern and western European immigrants. The bill did so by setting numerical limits on the number, per year of immigrants that would be allowed into the country from each region of Europe. ${ }^{23}$ This bill furthered the idea of the Nordic theory. The 1918 bill was not passed, but the bill's emphasis on numerically limiting immigrants was the inspiration behind the Immigration Act of 1924. The New York Times, in Grant's 1937 obituary, described The Passing of the Great Race as "besides being a recognized book on anthropology, it has often been called to Congressional attention in the passage of restrictive immigration laws ... Mr.Grant... helped frame the Johnson Restriction Act of 1924." ${ }^{24}$ The Immigration Act was widely praised by German eugenicists at the time. Bavarian Health Inspector Walter Schultz wrote that "German racial hygienists should learn from the United States how to restrict the influx of

\footnotetext{
${ }^{18}$ Charles C. Alexander, "Prophet of American Racism: Madison Grant and the Nordic Myth," Phylon 23, no 1 (1st Qtr., 1962), 78.

${ }^{19}$ Spiro, Defending the Master Race, xi.

${ }^{20}$ Ibid, 158.

${ }^{21}$ Ibid, xi.

${ }^{22}$ Harvard University, “Constitution of the Immigratrion Restriction League," http://pds.lib.harvard.edu/pds/ view/5233215.

${ }^{23}$ Harvard University, “Immigration Restriction League,1918," http://pds.lib.harvard.edu/pds/view/ 6526866.

24 “Madison Grant and the Racialist Movement," last modified July 16, 2010, http://www.amren.com/news/ 2010/07/madison_grant_a/.
} 
Jews and eastern and southern Europeans."25 Adolf Hitler also praised the law in his 1924 book Mein Kampf for excluding "undesirables" on the basis of hereditary illness and race. ${ }^{26}$

In 1929, America started utilizing the pesticide Zyklon B to delouse Mexicans as they crossed the border. The negative effects of the chemical were widely known at the time. The El Paso Herald reported that Zyklon B's active component, "hydrochloric acid gas, the most poisonous known, more deadly even than that used on the battlefields of Europe, is employed in the fumigation process." The use of the chemical inspired German doctor Gerhard Peters to suggest its use in Germany in a 1937 article. The article included two pictures of the El Paso delousing chambers. Peters' article explained Zyklon B's effectiveness in killing pests. In 1940, Peters became the managing director of Degesch. Degesch was one of the two German firms which had acquired the patent to produce Zyklon B in Germany. In 1946, Peters was tried, convicted and sentenced to five years in jail during the Nuremberg trials for his role in the production of Zyklon B. ${ }^{27}$

Another link between German and American eugenics involved funding. The New York based Rockefeller Institute began funding select German eugenicists. By 1926, the Institute's funding had become more widespread amongst German eugenicists, and totalled around $\$ 410,000$ American, or about four million dollars in today's money. In 1927, the Rockefeller Institute also contributed \$250,000 towards the creation and funding of the Kaiser-Wilhelm Institute for Anthropology, Human Genetics and Eugenics and another $\$ 317,000$ in 1929 . The money that the Kaiser-Wilhelm Institute received was for the most part under the control of "Hitler's medical henchman" Ernst Rudin. Rudin was a prime director of the "murderous experimentation" inflicted upon the Jews, Gypsies and other undesirables. $^{28}$ The Kaiser-Wilhelm Institute continued to receive funding from the Rockefeller Institute until the United States entered the Second World War in 1941. ${ }^{29}$

American eugenicists were very interested in twins, as they thought twins would help them further their research. In May of 1932 the Rockefeller Foundation pledged $\$ 9,000$ over three years to the Kaiser-Wilhelm Institute for the study of twins. The man in charge of this program for the Kaiser-Wilhelm Institute was renowned German eugenicist Otmar Freiherr von Verschuer. Verschuer was assisted by the infamous Nazi Doctor, Dr. Josef Mengele. Eventually both Verschuer and Mengele moved their experiments to Auschwitz, where Mengele would proceed to the horrific and deadly experiments that he is known for today. ${ }^{30}$

The Nazis introduced the Law for the Prevention of Hereditarily Diseased Offspring on July 14, 1933. The Nazi law had been inspired by the work of one of America's most prominent eugenicists Harry Laughlin. Laughlin believed that immigrants to the United States, the feeble minded, and the children of mixed race couples were were causing a

\footnotetext{
${ }^{25}$ Kuhl, The Nazi Connection, 25.

${ }^{26}$ Adolf Hitler, Mein Kampf, trans. DC Watt (London: Jaico Publishing House, 1974), 400.

27 David Dorado Romo, Ringside Seat to a Revolution: An Underground Cultural History of El Paso and Juarez: 1893-1923 (El Paso: Cinco Puntos Press, 2005), 240-243.

${ }^{28}$ Edwin Black, "Eugenics and the Nazis -- the California Connection," San Francisco Chronicle, November 9, 2003, 4.

${ }^{29}$ Volker van der Locht, "Eugenics: Germany," In Encyclopedia of Disability, edited by Gary L. Albrecht, 626-628.

${ }^{30}$ Black, "Eugenics and the Nazis," 5.
} 
"great mass of defectiveness" and were destined to become the majority of the American population. He believed that the "pioneer families" of America were the apex of Nordic purity. He also believed that early American settlers and Germans shared a "common race descent." ${ }^{31}$

Laughlin's Model Sterilization Law of 1914 was the basis of the Nazis' Law for the Prevention of Hereditarily Diseased Offspring. Laughlin wrote his law as a response to the infrequent utilization of already existing sterilization laws of various American states. Laughlin's law was harsher than many of the laws created by the individual states, and was also more comprehensive. Laughlin's law was also utilized as a basis for laws that many American states instituted after the model law was published. The law was a fairly tight piece of legislation that removed many of the subjective qualities of already enacted state laws. ${ }^{32}$ A report on the new Nazi law, which was funded by the Carnegie Foundation, observed:

It is fair to state that the Sterilization Act is not a product of Hitler's regime in that its main tenets were proposed and considered several years earlier before the Nazi regime took possession of Germany. There is no doubt that the Act conforms closely with present knowledge of medical eugenics. ${ }^{33}$

Laughlin praised the Nazi law and noted its similarity to his model law in the Eugenical News:

Doubtless the legislative and court history of the experimental sterilization laws in the 27 states of the American union provided the experience which Germany used in writing her new sterilization statute. To one versed in the history of eugenical sterilization in America, the text of the German statute reads almost like the "American model sterilization law." 34

In 1936, the Nazi's acknowledged Laughlin's role in helping them develop their sterilization laws, by choosing Laughlin to receive an honorary degree of Doctor of Medicine from the University of Heidelberg for his work in the "science of racial cleansing." In addition to praising Laughlin's work on eugenical sterilization, Laughlin's invitation also referenced his work in bringing about immigration restriction and anti-miscegenation laws. Laughlin stated that he had "deep gratitude" for the honor, "because it will come from a nation which for many centuries nurtured the human seed-stock which later founded my own country." Laughlin was unable to attend the ceremony due to funding restrictions but stated that the degree demonstrated "a common understanding of German and American scientists of the nature of eugenics." 35 Clearly, there was a mutual admiration between eugenicists in the two countries.

In 1937, Laughlin, backed financially by textile titan Wickliffe Draper, established the pro-eugenics organization, the Pioneer Fund. One of the Pioneer Fund's first acts was to

\footnotetext{
${ }^{31}$ Paul A, Lombardo, “The American Breed," Albany Law Review 65, no. 3 (February 2002) 746.

32 "Model Law," In Cambridge Dictionary of Human Biology and Evolution. Cambridge: Cambridge University Press, 2005.

${ }^{33}$ Hugh Gregory Gallagher, By Trust Betrayed: Patients, Physicians, and the License to Kill in the Third Reich (St. Petersburg: Vandamere Press, 1995) 93.

${ }^{34}$ Harry H. Laughlin, "Eugenical Sterilization in Germany," Eugenical News vol 18.5 (1933) 89.

35 Paul A. Lombardo, Three Generations, No Imbeciles: Eugenics, the Supreme Court, and Buck v. Bell (Baltimore: John Hopkins University Press, 2010) 211-213.
} 
distribute a Nazi propaganda film entitled Erbkrank in America. The film depicted the horrid living conditions within the slums of a German city, contrasted with pictures of the fancy, and expensive looking institutions for disabled Germans of "socially inadequate and degenerate family-stocks." ${ }^{36}$ The distribution of the film in America was meant to attempt to convince the American public to accept harsher eugenics laws, like those which were then being enacted in Germany.

In 1940, the Nazi government engaged in eugenically inspired mass murders of its own citizens, gassing people in old age homes and mental institutions. Between 50,000 and 100,000 German citizens were killed in this fashion. At this point it was clear to many American eugenicists that the Germans were now at the forefront of the movement. In fact, the Nazis were being perceived as leading the Americans in the endeavour of eugenics as early as 1934 after passing the aforementioned mandatory sterilization legislation entitled the Law for the Prevention of Hereditarily Diseased Offspring. By the end of 1934, Germany was sterilizing over 5,000 people a month. Although the Germans were, as superintendent of Virginia's Western State Hospital Joseph DeJarnette said, "beating us at our own game," the Americans were not bitter. Some American eugenicists seemed to take pride in their contribution to the Nazi eugenics movement. C.M. Goethe, founder of the Eugenics Society of Northern California, boasted to a fellow eugenicist upon returning from Germany that:

You will be interested to know that your work has played a powerful part in shaping the opinions of the group of intellectuals who are behind Hitler in this epoch-making program. Everywhere I sensed that their opinions have been tremendously stimulated by American thought...I want you, my dear friend, to carry this thought with you for the rest of your life, that you have really jolted into action a great government of 60 million people. ${ }^{37}$

Others, like executive secretary of the American Eugenics Society, Leon Whitney, took the opportunity brought about by the Nazi government's success in instituting harsh eugenics programs to criticize their own country's lack of advancement in the field. Whitney said in reference to Nazism, "while we were pussy-footing around...the Germans were calling a spade a spade." ${ }^{38}$

The Holocaust is one of the most atrocious events in human history. The foundation of the Holocaust lies within the international eugenics movement of the late 19th and early 20th centuries. Although the Nazi eugenics movement became more extreme than any other similar movement in the world, America was the first country to pass eugenics based legislation, and for much of the early 20th century led the world in the field of eugenics. It is evident that Nazi eugenics was associated with the American movement through various links between eugenicists and pro-eugenics organizations in both countries.

\footnotetext{
${ }^{36}$ Ibid, 213.

${ }^{37}$ Black, "Eugenics and the Nazis," 4.

${ }^{38}$ Ibid
} 


\section{Bibliography}

Alexander, Charles C. "Prophet of American Racism: Madison Grant and the Nordic Myth." Phylon 23, no 1 (1st Qtr., 1962): 73-90.

American Renaissance. "Madison Grant and the Racialist Movement." Last modified July 16, 2010. http://www.amren.com/news/2010/07/madison_grant_a/.

Black, Edwin. "Eugenics and the Nazis -- the California Connection." San Francisco Chronicle, November 9, 2003.

Eugenics in America. “Eugenics in California.” Last modified 2012. http://eugenicsinamerica.weebly.com/eugenics-in-california.html.

Forrest, Derek William. Francis Galton: The Life and Work of a Victorian Genius. London: Taplinger Pub Co, 1974.

Gallagher, Hugh Gregory. By Trust Betrayed: Patients, Physicians, and the License to Kill in the Third Reich. St. Petersburg: Vandamere Press, 1995.

Galton, Francis. Inquiries Into Human Faculty and Its Development. London: Macmillan, 1883.

Glueok, Bernard. "Reviews and Criticisms." Journal of the American Institute of Criminal Law and Criminology, Vol. 4, No. 6 (Mar., 1914), 934-935.

Grant, Madison. The Passing of the Great Race (4 ed.), New York: C. Scribner's sons, 1921.

Harvard University. "Constitution of the Immigration Restriction League." http://pds.lib.harvard.edu/pds/view/5233215.

Harvard University. "Immigration Restriction League,1918." http://pds.lib.harvard.edu/pds/view/6526866.

Hitler, Adolf. Mein Kampf, trans. DC Watt, London: Jaico Publishing House, 1974.

Indiana General Assembly. “1907 Indiana Eugenics Law.” Last modified May 7, 2013. http://en.wikisource.org/wiki/1907_Indiana_Eugenics_Law.

King, Robert C., Mulligan, Pamela K., Stansfield, William D. "Eugenics" in A dictionary of Genetics, Oxford: Oxford University Press, 2013. http://library.mtroyal.ca:2299/view/10.1093/acref/9780199766444.001.0001/ acref-9780199766444-e-2199. 
Kuhl, Stefan. The Nazi Connection: Eugenics, American Racism, and German National Socialism. Oxford: Oxford University Press, 2001.

Laughlin, Harry H. “Eugenical Sterilization in Germany." Eugenical News vol 18.5 (1933): 89-90.

Lenz, Fritz. "Eugenics in Germany." trans. Paul Popenoe, Journal of Hereditary, 15 (5):223-231.

Lombardo, Paul A. "The American Breed." Albany Law Review 65, no. 3 (February 2002): 745-830.

Lombardo, Paul A. Three Generations, No Imbeciles: Eugenics, the Supreme Court, and Buck v. Bell. Baltimore: John Hopkins University Press, 2010.

"Model Law." In Cambridge Dictionary of Human Biology and Evolution. Cambridge: Cambridge University Press, 2005. http://library.mtroyal.ca:2200/content/entry/cuphbe/model_law/0.

Pearson, Karl. The Life, Letters and Labours of Francis Galton, Volume 3. Cambridge: Cambridge University Press, 1930.

Proctor, Robert. Racial Hygiene: Medicine Under the Nazis. Cambridge: Harvard University Press, 1990.

Romo, David Dorado. Ringside Seat to a Revolution: An Underground Cultural History of El Paso and Juarez: 1893-1923, El Paso: Cinco Puntos Press, 2005.

Spiro, Jonathan. Defending the Master Race: Conservation, Eugenics, and the Legacy of Madison Grant, Burlington: Vermont, 2008.

Turda, Marius and Weindling, Paul. Blood and Homeland: Eugenics and Racial Nationalism in Central and Southeast Europe, 1900-1940. Herndon: Central European University Press, 2006.

Van der Locht, Volker. "Eugenics: Germany." In Encyclopedia of Disability, edited by Gary L. Albrecht, 626-628.

“Want More Babies in Best Families." New York Times, September 25, 1921. 